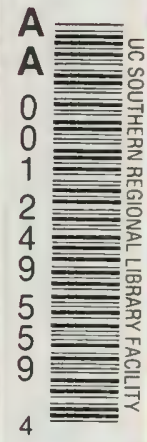

Water's

Development of the Phili 


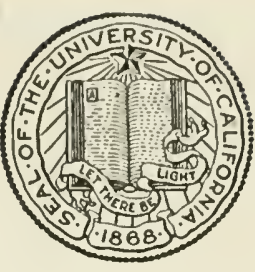

THE LIBRARY

OF

THE UNIVERSITY OF CALIFORNIA LOS ANGELES

GIFT OF

Clark J. Milliron 


\title{
The Development of the Philippines
}

\author{
A Summary of the Results of Special \\ Investigations made by Henry Jackson \\ Waters, President of the Kansas State \\ Agricultural College, by authority of an \\ Act of the Legislature of the \\ Philippine Islands
}


- 


\section{CONTENTS}

Letter of transmittal

The business of the Philippines.................................................................... 8

Stressing important industries ................................................................... 10

An uninterrupted program ............................................................... 11

Agricultural instruction and development......................................... 12

Uniting the agricultural forces............................................................... 14

Uniting the educational forces............................................................... 18

The College of Agriculture.................................................................... 20

The live-stock industry ........................................................................... 24

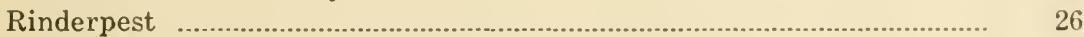

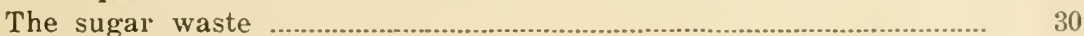

Sugar school .................................................................................................. 32

Experimental and demonstration stations................................................. 33

Disseminating agricultural knowledge ..................................................... 33

Feeding the people ..................................................................................... 35

Increasing the fish supply ............................................................................. 37

Relieving population pressure ...................................................................... 39

Setting the people to work ....................................................................... 41

The household industries ............................................................................... 41

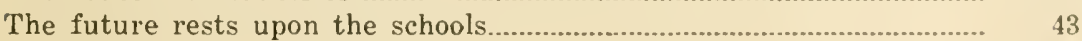

The solidarity of the people ........................................................................ 



\section{LETTER OF TRANSMITTAL}

Manila, September 25, 1914.

SIR: I have the honor to submit the following summary of the results of an investigation of the agricultural conditions and possibilities of the Philippine Islands. Acting under your instructions, I spent four and a half months-from May 8 to September 20, 1914-in collecting and in compiling the data upon which the report is based. During this time I visited most of the islands and nearly all of the provinces, making a personal investigation of the natural resources of the country, of the development and work of the schools, and of the agricultural practices of the people.

Every possible facility for carrying on the investigation was afforded by Your Excellency, the President of the University of the Philippines, the Director of the Bureau of Education, the Director of the Bureau of Agriculture, the Director of the Bureau of Science, the dean of the College of Agriculture, the governors of the provinces, the officers of the Constabulary, and the people of the Islands.

I beg leave to make acknowledgment of the uniform courtesy extended me by the officers of the Government, and by all the people whom it was my pleasure to meet.

Respectfully submitted.

H. J. WATERS.

To His Excellency the Governor-General.

(Through the Honorable the Secretary of Public Instruction.) 



\section{THE DEVELOPMENT OF THE PHILIPPINE ISLANDS}

One cannot go about over the Islands or study the statistics of production of the Philippines in comparison with those of other countries without being impressed with the fact that they are very far from being developed. The Bureau of Lands estimates that less than half the agricultural lands of the Islands, or approximately $7,000,000$ acres, are in cultivation. When the agricultural lands of the Philippines are as completely occupied as are the farming lands of Japan, for example, the Philippines will have a larger area under the plow than has Japan.

Two courses are open for the development of the Philippine Islands. A slow development which reserves the resources of the country entirely for the use of the Filipino, and a rapid development, similar to that which occurred in the United States, through the opening of its doors without restriction to the people of the world, and similar to that which is now taking place in Canada through the same means.

Within a quarter of a century the area under the plow in the United States was doubled. Labor-saving machinery, immigration from northern Europe, capital from the mines and from a large balance of the trade, all contributed to this result. In the Philippines the mines are not yet developed, and labor-saving machinery cannot enter so largely into the system of farming as it does in the States. Immigration to furnish the labor and capital for developing fully and quickly the resources of the Philippines would have to come from China, Japan, and India, and capital for the present would have to come from the outside. Capital would quickly follow labor under conditions insuring the safety of the investment.

Except in an industry which requires large capital and large land areas under one management, as the sugar industry, the Philippine Islands will naturally develop as family farms instead of as haciendas. But both of these types of farming are necessary to the proper development of the Philippines. The Government should quickly recognize the difference in the requirements of those phases of agriculture which require large areas, much capital, and ample powers, and those which may be best organized as household farms. 
But the increased earnings of the Philippine people should not come from increasing the area under the plow. The cultivated land must be made to yield a larger harvest. The Japanese farmer, for example, produces $12,000,000,000$ worth of wealth a year from $14,000,000$ acres of land, and the Filipino farmer produces only $\$ 200,000,000$ worth of products from $7,000,000$ acres. From twice the area the Japanese farmer produces tenfold the wealth that the Filipino farmer does.

If the sugar planters of the Philippine Islands harvested as much sugar to the acre as do the planters of Java, the Philippines, without increasing the area in cane, would be the leading cane sugar producing country in the world, Cuba alone excepted.

If the rice growers of the Philippines obtained as high acre yields as clo the rice growers of Japan or the United States, instead of buying from India and Japan one-fourth of the rice consumed in the Islands, the Philippines would be the third largest rice-exporting country in the world.

If the acre yield of corn in the Philippines equal that of the United States or Japan, the Philippine Islands would have grain enough to support a larger pork and poultry industry than has either Canada or Australia.

These are among the possibilities of the Islands with less than half the reasonably good agricultural land in cultivation. When all the land is utilized to the limit of its producing power, when the fisheries, manufactures, and commerce of the Islands are developed, enough food and wealth will be produced to support comfortably $40,000,000$ people, or as many people as are in France or in the United Kingdom of Great Britain.

THE BUSINESS OF THE PHILIPPINES

Last year the value of the purchases of the people of the Philippines amounted to $\$ 5,250,000$ more than the value of their sales. A study of the business of the Islands reveals many wastes. For example, 9,000,000 pounds of raw sugar were sold from the Islands at an average price of 4 centavos a pound, all of which, or its equivalent, was bought back again as refined sugar at 10 centavos a pound. What was sold, therefore, for $¥ 360,000$ was bought back for $¥ 900,000$. It cost approximately ${ }^{*} 140,000$ to refine this sugar. The balance, $\$ 400,000$, was absorbed in transportation charges and profits to people who, for the most part, live in other countries.

One may ride for days through grass up to the saddle skirts without seeing a herd of cattle or horses. Meanwhile, the people of the Philippines are paying the farmers of Australia and 
India about $* 3,500,000$ annually for meat and work stock. It is probable that there is enough grass and forage of fair nutritive value going to waste each year in the Philippines to produce all the meat that is now imported from foreign countries. Besides, if the waste places and mountain sides were closely pastured the year through, there would be less frequent and less serious locust infestations.

With almost limitless forest resources, the Philippines last year bought more than $1 * 1,000,000$ worth of lumber outside of the Islands.

Last year purchases were made outside the Islands aggregating $\$ 25,000,000$, on which the people of the Philippines paid an import duty of some $¥ 5,000,000$, all of which materials the Islands are capable of producing without beginning to tax the resources of the soil or people.

The articles sold from the Islands are principally raw materials, which support manufacturing industries and give employment to labor in other countries. For example, one of the important benefits of the coconut industry is lost when copra instead of coconut oil is exported. By exporting oil instead of copra, a home industry would be developed, a substantial profit now going almost wholly to people outside the Islands would be saved, and the coconut cake would be left at home as an excellent food for poultry, hogs, and horses.

It is good business for a people to produce as nearly as possible everything they need and to buy outside of the country as few things as possible. A favorable trade balance is essential to the development of a new country, to furnish the means with which to build schoolhouses, highways, and new industries.

The credit of the people is limited and the interest rate is high in a country that has a poor soil, an uncertain climate, an unstable government, defective land titles, or low labor income. Yet this is just the kind of a country whose people are least capable of paying a high interest rate or of supplying their own capital.

The Filipino farmer suffers the natural and irremediable handicap of floods, droughts, and typhoons. He suffers also from the remediable handicaps of defective land titles and a small family income. He sells the products of his labor at an inopportune season and at a low price and buys his supplies in small quantities at a high price. Whatever may be said of him as a producer, the Filipino farmer, like the American farmer, is more successful as a producer than he is as a buyer and seller.

The Government should as speedily as possible remedy the $130395-2$ 
defects in land titles in the Philippines. This alone will greatly improve conditions. The Government should also extend as rapidly as possible the benefits of the Agricultural Bank. Cooperation between the producers and the consumer's should be promoted in such a way as to reduce materially the cost of doing business in the Islands. The family income should be increased by increasing the area tilled by the farmer and by creating profitable industries suited to all the members of the family.

\section{STRESSING IMPORTANT INDUSTRIES}

It is easy to point out defects in a system of agriculture, but it is difficult, indeed, to suggest feasible remedies. It is too much to hope that the conditions in the Islands will be speedily remedied. Rural people in any country are conservative and adopt new practices slowly. It is a work in which every citizen must have a part. Obviously, it will add much to the effectiveness of the campaign if a general policy is adopted and if all work to the same end instead of each trying to promote development along the lines in which he happens to be interested.

The greatest hope lies in developing along the lines of staple crops and the classes of live stock that are well adapted to the Islands. The Philippines must henceforth as at present be essentially a rice, corn, sugar, copra, hemp, tobacco, carabao, cattle, poultry, pig, and pony producing country. Development along these lines is safe and sure, and there is abundant room for improvement in each. Special crops, such as citrous fruits, coffee, cacao, rubber, kapok, silk, and tea, should be encouraged in special localities, but emphasis everywhere and at all times should be placed upon the principal industries.

A larger and better laying hen, such as has been developed in South China and which appears to be well adapted to the Philippines, would be able to turn the balance of trade of the Islands from the wrong to the right side of the ledger. Crossing the Philippine pony with Australian or Arabian stock has produced an animal better adapted to the needs of the Islands than is the present stock. Galloway and Indian cattle mix well with the native stock, as has been demonstrated by the Bureau of Agriculture, and their offspring make a very satisfactory beef animal. As much as 50 bushels of rice to the acre has been produced by the agronomists of the Bureau of Agriculture by the use of better seed. The average vield of rice in the Philippines with unimproved seed is less than 12 bushels an acre. The Bureau is producing the seed of these improved strains 
in large quantities for distribution among the rice growers of the Islands.

Examples might be multiplied indefinitely of the improvements that are within the reach of the average farmer. All efforts at improvement must begin where the Filipino farmer now is, and must offer reforms that are within his reach.

\section{AN UNINTERRUPTED PROGRAM}

The development program must go forward without interruption. Changes in the directorship and in other positions in the Bureau of Agriculture have occurred with great frequency. With each change in the administration of the Bureau has naturally come a change in policies. The Bureau has been so overloaded with police duties that it has had little time and money left for large constructive work. There has also been a tendency on the part of the Bureau in the past to extend its field of work rather more rapidly than the available funds would justify. The present policy of the board, fortunately, is to concentrate upon a limited number of lines and to emphasize the basic industries of the Islands.

With the larger plans of the Bureau must come a greater stability in the tenure of office of the men who are to do the work. This is impossible so long as the scale of salaries is fixed by the Legislature. Indeed, the elementary weakness in the administration of the Bureaus it was my duty to study, lies in the fact that the Legislature fixes the salary that is attached to each position in the service. When a man develops beyond the salary fixed for the position he holds, or is offered a better salary elsewhere, either he must be advanced in rank and responsibility, as well as in salary, or his services are lost to the Government. Obviously, it is not practicable to promote a man in rank every time that it is deemed wise to increase his pay ever so slightly. As a result, as soon as a man has gained sufficient knowledge of local conditions and of the needs of the people of the Islands to begin to be really useful, his connection with the service is too frequently severed and a new man, inexperienced in the Philippines and unacquainted with the local conditions, is put into his place. On the other hand, if a reasonable proportion of the strong men are held in the service through promotion in rank and in salary, the organization of the Bureau soon becomes top-heavy because too many men occupy administrative and supervisory positions, and too few good men are kept at work in the field of their specialties. 
The system of fixing by statute the salary for each position is neither economical nor efficient. A number of years ago, this system of conducting the business of the Government bureaus was common in the United States. In some States the legislatures went so far as to fix by statute the salaries of the oflicers and teachers of the universities and agricultural colleges. At present every State with which I am acquainted makes its appropriations to its institutions and bureaus in bulk, giving such directions as it deems wise regarding the ways in which the money appropriated shall be expended.

It will greatly improve the service and effect a decided economy if in the Bureaus of Agriculture and Education the appropriations are made in one or more lump sums and if the Secretary of Public Instruction and the chief of the Bureau in each case are empowered to fix the scale of salaries and to make all promotions in rank on merit.

\section{AGRICULTURAL INSTRUCTION AND DEVELOPMENT}

There are six governmental agencies in the Philippines giving instruction in agriculture or engaged in agricultural development:

1. 'The Bureau of Agriculture.

2. The Bureau of Education.

3. The College of Agriculture.

4. The Bureau of Forestry.

5. The Bureau of Science.

6. The College of Veterinary Medicine.

The Bureau of Agriculture creates agricultural knowledge through its experimental work and its field studies. It disseminates this knowledge through published reports and bulletins, through field demonstrations, and by personal contact with farmers. Also, the Bureau is trying to improve the agriculture of the Islands by introducing, propagating, and disseminating new plants and animals. So far the Bureau of Agriculture has dealt only with the adult.

The Bureau of Education teaches agriculture in its schools, through its gardens and farms, through corn-growing campaigns, and by means of published circulars and bulletins. The Bureau of Education also propagates and disseminates improved plants and animals, conducts farm demonstrations, and coöperates with farmers in making tests of new methods and new crops. At the Cavite Farm School, for example, the Bureau of Education is covering practically all fields of activity of the 
Bureau of Agriculture. The principal spends much time away from the school, working with the farmers, conducting demonstrations in rice and corn growing, and in teaching the farmers how to improve their poultry. On the school grounds there are numerous experimental plots used for testing the adaptability of new crops to the condition of the province. New strains of corn have been developed at the school and an improved stock of chickens has been brought from China and propagated extensively for distribution. The Bureau of Agriculture keeps an agricultural inspector in the province, but there is no attempt by the two Bureaus to coöperate or to divide the field.

The College of Agriculture seeks to create agricultural knowledge through its experimental work, and to improve the agricultural practice of the people by the introduction of better plants and by creating new strains of plants. The college disseminates agricultural knowledge through its students, by means of circulars and bulletins, and by personal contact with farmers.

The Bureau of Forestry is charged with the duty of conserving the timber resources of the Islands and of creating new resources by reforesting waste lands. The Bureau gives instruction in tree planting and timber management. Elaborate reports are published giving the results of the Bureau surveys and forest studies. The Bureau, in coöperation with the College of Agriculture, maintains a school of forestry at Los Baños.

The Bureau of Science seeks to improve the agricultural conditions of the Islands through its study of insect pests, soils, varieties of sugar cane, and by the operation of a sugar-testing laboratory.

The College of Veterinary Medicine is contributing to agricultural development and progress by training men to serve as Insular and provincial veterinarians and by helping to hold the diseases of domestic animals in check.

This situation cannot fail to create some confusion in the minds of the people who try to apply the teachings of these Bureaus and colleges, because of the differences in the teachings of the diflerent organizations with respect to the same subject. For example, four of these agencies are seeking to help the farmer control insect pests, but there is not always entire agreement among them as to the remedics proposed. With the Bureau of Education recommending one method, the Bureau of Science another. the teachers at the College of Agriculture another, and the Bureau of Agriculture pursuing a different method from any of the others, what must be the 
state of mind of the farmer who is seriously seeking the best means of protecting his crops against the ravages of insects? With the Bureau of Education teaching the school children to follow one method of selecting seed corn, or of preparing soil for rice, and the Bureau of Agriculture recommending to the parents of these children another method, the confusion is complete, and the public confidence in much of the agricultural teaching is shaken.

This overlapping has been the result of a very rapid development, and the natural outgrowth of a condition where there was more to do than the agencies at work could accomplish. Some of the duplication is economical and justifiable and some of it is unnecessary and wasteful.

Contrary to expectations, I found very little destructive rivalry in the Bureaus and institutions studied and there was every evidence of a desire on the part of the officers of each institution to recognize the natural field of work of the others and an entire willingness on the part of each fully to coöperate with the other. It will be comparatively easy, therefore, to substitute for the duplication pointed out a most effective system of coöperation.

\section{UNITING THE AGRICULTURAL FORCES}

The work of the Bureau of Agriculture, the Bureau of Forestry, the College of Agriculture, and the College of Veterinary Medicine falls into the same general class. Especially is there no natural line of demarcation between the fields of operation of the Bureau of Agriculture and the College of Agriculture. Any attempt to maintain an arbitrary line between these two institutions and to make each respect the field of work assigned to the other will result in an inefficient Bureau and a weak college. To allow buth to spread out over the whole field is likely to increase the cost of maintenance beyond the power of the Government to meet it.

In a country as extensive and wealthy as the United States, a Federal Department of Agriculture at the National Capitol and a college of agriculture in each State is the logical arrangement, though the cost of maintaining this system of agricultural education and research in the United States is nearly \#100,000,000 a year, or about half as much as the income from all the farms in the Philippines.

If the Philippine Islands were large enough to warrant the establishment of a seperate college of agriculture in each of the provinces, then a strong Insular Department of Agriculture 
at Manila, properly to correlate the work of all the provincial colleges and experiment stations would be necessary. As far as the College of Agriculture is concerned, however, it would seem to be wiser to continue the policy already entered upon, of maintaining farm schools in the provinces, like the one at Muños or the one at Cavite, and to have one strong agricultural college for the entire Archipelago. The teaching of agriculture in the public schools should be emphasized much beyond even the present point and the work in agriculture in the public schools, the farm schools, and the Agricultural College should be so carefully correlated that a pupil may pass from one to the other without waste of time or loss of credits.

The proper correlation of the agricultural forces of the Philippines is by no means simple or easy. There is room in the Philippines for one strong organization in agriculture, covering instruction, experimentation, and demonstration. Either all the agencies now existing should be merged into one organization, or at most two organizations-a College of Agriculture and a Bureau of Agriculture.

In any case, the principal experimental work should be done on the college grounds and the men engaged in experimental work should be located where they may have constantly under their eye the crops or animals with which they are experimenting.

There is much work being done by the Bureau of Agriculture on its own grounds that could be done to better advantage at the college. The Bureau maintains several institutions for the propagation of plants and animals for distribution over the Islands. Isolated as they are, they serve no purpose as teaching institutions, whereas if located on the campus of the College of Agriculture they would be most useful for purposes of instruction, at the same time that they would be as useful as they now are as propagating stations. By concentrating all these activities at one place, considerable saving in the cost of maintenance could be made, and by bringing this work to the college, the students would have an opportunity to perform a considerable part of the labor required, thus helping themselves through college as well as gaining valuable experience.

At Lamao, for example, the Bureau of Agriculture conducts an extensive nursery for the improvement, propagation, and distribution of plants. Owing to the isolated location of the station, very few people visit the grounds and the splendid work being done there is completely hidden from the view of the agricultural students at Los Baños. Therefore, the Agricultural College is obliged to maintain an extensive nursery of its 
own for instructional and experimental purposes, but the college has no means of distributing the surplus products of its nursery and many of them go to waste. One nursery located on the college grounds would serve all the purposes that the two now serve.

The Bureau of Agriculture also maintains an extensive establishment at Alabang for breeding horses, cattle, and hogs for distribution and for sale. The splendid equipment there serves only one purpose, that of producing animals. At the Agricultural College, the teaching and experimental work in animal husbandry is lamentably weak for the want of just such equipment as is at Alabang. Therefore, the Government faces the alternative of purchasing at an expense of not less than $\neq 20,000$ suitable live-stock equipment for the college or of transferring to the college such of the animals now at Alabang as are needed for teaching purposes. The animals will serve the purpose of propagation quite as well at the college as at a separate breeding station, and they will be even more useful for teaching purposes if they are also made to serve as breeding animals and if their offspring are distributed over the Islands.

The work in agronomy, animal husbandry, horticulture, and veterinary medicine in the Bureau of Agriculture and in the College of Agriculture should be brought together, and each division or subject should be placed in charge of one man instead of being in charge of two as at present. This applies to the experimental work as well as to the work in instruction and extension.

The Bureau of Forestry.-The forest resources of the Islands are very important, indeed, and there is no reason to suggest a curtailment of the work of the Bureau of Forestry any more thian it would be wise or profitable to curtail the activities of the Bureau of Agriculture or of the College of Agriculture. But it will greatly simplify the organization of the work, without interfering in any degree with the efficiency of the Bureau of Forestry, to have the Bureau made a division of the Bureau of Agriculture or a part of the Agricultural College.

The Teterinary College.-The live-stock interests of the Philippine Islands are not likely to be dereloped to such an extent as to require the services of many veterinarians. There are perhaps fewer than a dozen cities in the Islands that could support a private veterinarian. It is not likely that the Government will need more than an average of one veterinarian to each province. Thus there is room for not more than 50 or 60 veterinarians in the Islands. Allowing an average of twenty 
y'ears as the active life of each veterinarian, the yearly requirement to replenish the natural loss through death would be but three new men once the original demand is supplied, and these three each year would not be required for many years to come.

Thus, within a short time all the Government positions will be filled and all suitable locations for private practitioners will be occupied and the graduates from the Veterinary College will be without an opportunity to practice their profession. It would seem wise, therefore, to consider the advisability of declining to accept new matriculants and to discontinue the college as soon as the students now enrolled in the college have graduated. The equipment of the college might go to the Bureau of Agriculture for use in its investigations, and to the College of Agriculture for elementary instruction in animal diseases. When the need arises for more veterinarians, the Insular Government could send some of the graduates of the Agricultural College to the United States to study veterinary medicine at much less expense than is required to maintain a reterinary college at home.

Under any plan of organization it seems likely that the Bureau of Agriculture would be obliged to maintain an office in Manila, from which all administrative and standardization work at least could be conducted. Also, to concentrate the technical work of the Bureau and the college at the college would probably make a necessary change in the location of the college to a point more convenient to Manila. In this event, the equipment now belonging to the College at Los Baños could be used to good advantage by the Bureau of Education for a provincial farm school. I do not pretend to be sufficiently familiar with the details of the situation even to suggest a new location in case it is decided to move the college; but Alabang appear's to be an ideal location in all respects, with the important exception that the land at Alabang is not very fertile and is not well adapted to some of the important crops of the Philippines, such as abacá and the coconut palm.

If Alabang were chosen as the new location of the college. the research work now in progress at Alabang could be transferred to the quarters belonging to the college at Pandacan. Manila, formerly occupied by the Veterinary College and now vacant. This would make the veterinary laboratory at Alabang available as a chemical or botanical laboratory for the college. The building is well built, is well designed for laboratory purposes, and is practically new.

The shed and pens for live stock; the wells, pumping plants. $130395-3$ 
water pipe lines, rice paddies; and roads that would be required by the college if it were located at Alabang are already provided there and probably would be a waste if the college remained at Los Baños. However, the abandoning of an equipment such as is at Alabang is a very small matter compared with a mistake in the permanent location of the College of Agriculture. Therefore, the advantage of a small temporary saving should not be allowed to weigh heavily in determining the new location of the college in case it is decided to move it.

If the college is brought to Alabang, it would be necessary to erect an administration and classroom building at a cost of perhaps $\$ 35,000$; an agronomy building, costing $\$ 15,000$; and another laboratory building at a cost of about $\$ 35,000$. This would give the college better equipment than it now has, but not better than it needs.

A rough estimate of the saving that would be effected by such a combination of the work as is proposed is as follows:

Cost of upkeep of grounds, roads, and buildings, and the saving of the cost of roads that are being built at the college, or must be built very soon

$+25,000$

Saving in salaries and cost of departments:

\begin{tabular}{|c|c|}
\hline Agronomy & $\mathbf{1} 4,000$ \\
\hline Animal husbandry & 4,000 \\
\hline Entomology & 2,00 \\
\hline Horticulture & 10,00 \\
\hline
\end{tabular}

Saving in the cost of live-stock equipment needed at the college.... 20,000 Saving in nursery work.............................................................. 15,000

Total

80,000

In this estimate no account is taken of the saving to be made by combining the work of the Bureau of Forestry with that of the college or the Bureau of Agriculture, and the saving that would result from closing the Veterinary College as soon as the students now enrolled are graduated. It is safe to assume that the saving in one year would be sufficient to meet the cost of the new buildings necessary to be erected at the college. The combinations suggested commend themselves, however, not so much upon the ground of economy of administration as upon the broader ground of greater efficiency.

\section{UNITING THE EDUCATIONAL FORCES}

It is much more difficult to correlate the work of the Bureau of Education with that of the Bureau of Agriculture and the College of Agriculture than it is to correlate the work of the 
more closely allied agricultural institutions. The extent to which the Bureau of Education has gone into the field of agricultural education and development, however, makes it very important that the closest coöperation be maintained.

The Bureau of Education with its organization of teachers and its close touch with the young people of the Islands is in a position to disseminate information much more rapidly and cheaply than is any other organization in the Islands.

The school gardens of the Bureau afford a splendid opportunity finally to try out in different regions plants and animals of undoubted commercial promise. The school gardens and farms also afford the best possible means of introducing new plants and methods into a community. It should be understood, however, that these gardens and farms are not test grounds and experiment stations. Experimental work at best yields but a small proportion of successes and a large proportion of failures. School children sow seeds and cultivate crops in the full confidence of an abundant yield, and it would be disastrous to the entire system of education to have these children repeteadly or even frequently disappointed in the harvest.

The Bureau of Education conducts elaborate tests of crops in all the provinces and is accumulating valuable data regarding the behavior of these crops under different conditions of soil and climate. Except as this information is helpful in teaching the children who come to these schools, it is of little value unless the Bureau of Education and the Bureau of Agriculture cooperate to bring this knowledge to the people.

Therefore, all the information developed on the school gardens and grounds should be available to the officers of the Bureau of Agriculture and the Agricultural College. An officer of one of these institutions should visit the principal school grounds and farms at the most opportune time each year for the purpose of studying the character of the different crops grown there. The officer should have access at all times to the records of the yields and to the observations and notes of the teachers concerning the crops grown in their gardens. This does not mean to suggest that the representative of the Bureau of Agriculture or of the Agricultural College should exercise any control over these gardens. Indeed, it should be clearly recognized that the gardens and farms are a part of the teaching machinery of the Bureau of Education and that the coopperation of the Burealu of Agriculture and the Agricultural College is maintained wholly with a view of helping to make them successful and most helpful to the school children and to the farmers. 
On the other hand, the Bureau of Education should not assume that knowledge of agriculture which would justify its officers in recommending a practice for any region or in putting such practice into effect through its schools and school gardens. These are functions of the Bureau of Agriculture and of the College of Agriculture. It is the business of the Bureau of Agriculture and of the college to shape the agricultural policies of the Islands as definitely as it is the business of the Bureau of Education to shape the educational policies of the Islands.

A matter of such great importance as the correlation of the work of several of the most important bureaus and institutions of the Government requires more than ordinary consideration and study. It is far too intricate and delicate a question for the Legislature to go into in the hurry of the session and with the many other important matters demanding attention. Therefore, I would recommend that the Legislature empower the Secretary of Public Instruction to make such combinations of the work and equipment of the Bureaus of Agriculture, Education, and Forestry, and of the Colleges of Agriculture and Veterinary Medicine as, in his judgment, after a full and careful study of the work of each, will increase their efficiency.

\section{THE COLLEGE OF AGRICULTURE}

It does not seem to be necessary or wise to create an independent institution at Los Baños, but the College of Agriculture is of too great importance to the people of the Philippine Islands to allow its isolation to be the cause of its neglect or in any way to interfere with its efficiency. There is every indication that the members of the board and the president of the university are in hearty sympathy with the purposes and work of the college, but it is difficult, under the present arrangements, for the board and the president to give the proper amount of personal attention to the affairs of the institution.

As a remedy, I would suggest that the board meet at the college at least quarterly, or, better, monthly, for the consideration of the needs of the institution, or, perhaps, better, that the immediate control of the college be vested in a special committee of the board, of which the president of the board would be chairman and of which the president of the university should be a member. The actions of the committee, of course, should be subject to revision and reto by the board. The executive committee of the board for the college should hold its meetings at the college and frequent opportunities should be given the dean 
and the heads of the departments through the dean, to report their needs.

In the interest of economy and efficiency, I would strongly recommend that the budget for the college be agreed upon and announced before the beginning of the fiscal year so that the officers may know what funds are available with which to carry on their work. It goes without saying that the dean of the college should prepare and recommend the budget for the consideration of the president and the board.

The courses of study.-The departments of botany and chemistry in the college are exceptionally well organized and well officered. In these fundamental sciences, the work of the college will compare favorably with that of the better colleges of the United States, but in the practical subjects the college is not nearly so far advanced. The curriculum requires all students to devote their entire time during the first two years to academic subjects as a preparation for the technical instruction which is to follow. Thus, all students are required to remain in the institution two years before they are permitted to receive instruction in agricultural subjects. In the third year only one agricultural subject is offered. In the fourth year the proportion of agricultural to cultural and scientific subjects is satisfactory. In the fifth and sixth years the agricultural work is concentrated and somewhat congested. In this respect, the present course of study in the Philippine College of Agriculture resembles the course of study in the American college of agriculture of twentyfive or thirty years ago. American teachers have learned the importance of introducing agricultural subjects at the very beginning of the course, and from the first they are giving practical and theoretical instruction side by side.

I would recommend that a strong and very closely supervised course of five hours in farm practice be added to the first year of the curriculum. This course should consist chiefly of the methods of performing modern farm operations-a sort of farm manual training course-wherein the student is taught how to do in the most approved fashion for the Philippines those things with which he will need to be perfectly familiar when he seeks to instruct others in modern farm practice. There does not seem to be any pressing need of eliminating anything now in the course of study to make room for agriculture, but to aroid overcrowding, German should be reduced to three hour's at week. I question seriously the wisdom of requiring these inadequately prepared students to take a strong course in Crermanic languages 
in the first two years of their college course. Certainly it has no justification as a preparation for reading the agricultural literature of the Germans for two reasons; because only 1 or 2 per cent of the students will ever have occasion to exhaust the agricultural literature available in English, and because the amount of instruction in German provided in the course is insuflicient to enable these few to read German readily. If the study of German gives the Filipino student a better grasp of the English language than does an equal amount of effort put upon the English itself, as is claimed by some, there is ample justification for keeping German in the course. On no other ground would I consider it to be justified.

In the second year, a full course in agriculture, dealing with the staple crops and laying emphasis upon plant judging and selection and upon the production of staple crops of the Islands, should be added. If it is found inexpedient to devote the entire year to crop studies at this point in the course with the limited knowledge the students have of chemistry and botany, it would be entirely feasible to devote half the year to animal husbandry.

To make room for agriculture in the second year, I would recommend the elimination of the course in German or its postponement until a later period when it might appropriately be offered as an elective to candidates for the degrees of bachelor of science. Valuable as the work in botany is, it will be found profitable, I am certain, when the agricultural work is well organized and highly developed, to omit a half year of botany or to make one full semester of the botany relate directly to the practical details of plant production.

By adding two years of agriculture and by giving three courses instead of two in animal husbandry, the course would be fairly well balanced for the present. Within a short time, however, it will be found advisable to increase the practical work even beyond this point. In agronomy the principal stress should be laid upon the six staple crops of the Islands; and in animal husbandry the work should be confined almost exclusively to a study of the carabao, work cattle, ponies, swine, and poultry.

Equipment.-The equipment of the college in botany, chemistry, and forestry is excellent. Indeed, there is an apparent tendency to over-equip botany by establishing a botanical garden at the college. The isolation of the college would seem to make it unwise to establish anything resembling an Insular botanical garden at Los Baños. Indeed, until the work in farm crops and live stock is well organized and equipped, I doubt the wisdom 
of organizing the botanical work of the college beyond its present development.

The equipment in agronomy is fair, but it should be greatly increased along the line of rice production, sugar and hemp plantings, and the good work now being done with corn and tobacco should be extended.

The equipment in animal husbandry is practically nothing. The college needs at least $¥ 20,000$ worth of live-stock equipment for instructional and experimental purposes.

Experimental work.-Up to the present time, the right, much less the duty, of the college to do experimental work does not seem to have been recognized by the governing powers. Nevertheless, the institution is carrying on considerable very good experimental work, but it has been necessary to make the experimental work too much a part of the instructional work of the college for the good of either. It takes the time and interest of the student from the more practical and useful subjects, and is likely to make of him an experimentalist rather than a farmer. The experimental work is likely to suffer because too much of it is left to the supervision of undergraduates.

No matter what is finally done regarding the merger of a part of the work of the College of Agriculture with that of the Bureau of Agriculture, the duty of the college to do good research work must be clearly recognized and the necessary funds should be provided. Strong men cannot be attracted to an institution or held there unless they are given an opportunity to discover new truths as well as to teach old truths. An agricultural college without experimental work soon becomes impotent.

Extension work.-To cut the Agricultural College off from the practical farmer works a hardship upon the college as well as upon the farmer. It is only a part of the duty of the modern college to teach acceptably the young men resident upon its campus. The college should carry its teachings out to the people for two very important reasons. The farmer needs all such instruction that the college can give him. Teaching the experienced farmer makes the instruction at the college much more practical than it otherwise would be. Instruction that is not practical or that is not adapted to the Philippines may be imparted to inexperienced college students indefinitely without being challenged; but the moment it is presented to the experienced man on the farm its deficiencies become apparent. Adaptation of the instruction to the farmer's needs is the crucial test. 
No one familiar with the subject of animal husbandry would think of the Philippine Islands as an important live-stock country when compared with such countries as the United States and Argentina. Yet, when compared with other tropical countries or when compared with a semitropical country like Japan, in the number of animals at least, the Philippines make a good showing. For example, there are in the Philippines about seven times as many hogs, four times as many goats, and thirty times as many sheep as there are in Japan, although there is only about half as much land in cultivation in the Philippines as in Japan. In the number of horses, however, the Philippines fall far short of Japan, there being only about one-seventh as many, and only about one-sixth as many cattle. The carabao in the Philippines, however, easily offset the difference in the number of horses in the two countries, and the only direction in which the Japanese farmer has developed his live stock beyond that of the Filipino farmer, as far as numbers go, is in cattle.

The Filipino farmer, however, has not yet learned the very important lesson that the Japanese farmer has only recently learned-the same lesson which the farmers in the States were a long time in learning-that real progress can come only through better breeding and better care of the animals.

Under the encouragement of the Government and through the assistance of one or more breeding farms in each prefecture, and the assistance of three federal breeding farms, Japan has made remarkable progress in recent years in the improvement of the grade and quality of her farm animals. For example, the total number of cattle in Japan increased only 9 per cent in the last ten years, but the number of improved cattle resulting from the crossing of the native cows with pure-bred bulls increased 150 per cent, and the number of cattle without improved breeding decreased 17 per cent. Ten years ago there were in Japan only 189,000 cattle carrying superior blood, whereas last year the census showed 479,000 such cattle.

In horses, the showing is even more striking. The number of unimproved, or scrub, horses has decreased one-fifth in the last ten years, while the number of horses with improved blood increased fourfold, or from 87,000 to 451,000 . Equally rapid progress has been made in grading up the swine and poultry of Japan.

A necessary step in progress in the Philippines is to require all breeding sires to be registered with the Government, and all 
males not acceptable for registry should be castrated. I realize that this would break into a long-established custom and would run strongly against public sentiment; but it is only through the enforcement of some such rule as this that progress can be made in stock improvement in an unfenced country and especially in a country where the animals are kept in very small groups as they are in the Philippines.

There is a large and important area in Mindanao and many smaller areas elsewhere in the Philippines very well adapted to the raising of cattle, carabaos, and ponies that are not being utilized for any purpose. After a visit to the open range of the Island of Mindanao, I am certain that no public land approximating in value as a cattle range that of the Bukidnon Province has been open to the settler in the United States within the last quarter of a century. I was told by those who have had experience with cattle on this range that a hectare of land will support a bullock the year through. Pasture land in the States that will support a bullock to the hectare half of the year has a market value of $¥ 50$ to $\$ \neq 75$ an acre and a rental value of $\neq 3$ to $\$ 7$ an acre a year.

The Government, through the Bureau of Agriculture, should establish a breeding farm in this region and manage the farm as a commercal cattle ranch, keeping an accurate account of the cost and returns, to demonstrate beyond question the possibilities of this region for stock growing. Once this fact is established beyond question, there will be plenty of capital available with which to develop the country.

The carabao is the most important domestic animal in the Philippines. The department of animal husbandry of the Bureau of Agriculture should make a careful study of the different types of carabao with a view of determining which type is best suited to the various purposes to which this animal is put in the Islands, and with a view of improving the type by selection and breeding.

The type of the Philippine hog, the next most important animal in the Islands, should be improved along the lines in which the Bureau of Agriculture and the College of Agriculture are now working.

The size and laying quality of the Filipino hen can be improved greatly through the means already adopted by the College of Agriculture and by the Bureau of Education at the Cavite Farm School.

In so far as it is feasible to import improved sires, it will be cheaper to do so than to breed them, but in the case of many kinds of stock the imported sires seldom do well and in all classes 
there is a distinct advantage in breeding from stock born in the Islands. In the importation of sires the Bureau of Agriculture should act for the individual farmer, combining into one importation many orders and thus save expense. It would be profitable to grant the Bureau a fund with which to import stock for sale to farmers at actual cost, the proceeds of the sales being reappropriated to the Bureau for the purposes of making importations. The fund might be considered a permanent capital with which the Bureau could do a live-stock importing business for the people. This, however, will not relieve the Bureau of Agriculture and the College of Agriculture of the responsibility of producing on their grounds as many good breeding animals as possible. It is not a just criticism to say that it costs the Government more to produce these animals than they bring when sold. The service they render in improving the quality of the stock of the Islands will much more than offset any such deficit.

At best only a small proportion of the stock owners of the Philippines have animals enough to warrant them in buying improved sires. Therefore, public breeding stations, such as the Bureau maintains at Batangas and at La Carlota, are the only means by which the man with small capital or with few animals can derive any direct benefit from the improved animals the Bureau or the college breeds or imports.

Universally the owner of scrub stock gives them scrub care, while the immediate effect of placing improved stock in the hands of the farmer is to increase his interest in them and to increase the intelligence with which they are fed and managed. In no country can progress in animal improvement outrun the intelligence with which the animals are fed, housed, and guarded against disease. Much of the present opposition to the enforcement of quarantine regulations in the Philippines will subside when the farmer has improved stock to be protected by such regulations.

\section{RINDERPEST}

The control of infectious diseases, whether of man or of domestic animals, has always been unpopular. Perhaps at no time since the Government of the United States undertook the control and suppression of contagious diseases among farm stock would the work have been allowed to proceed if left to the choice of the people most directly interested-the stock owners.

In all European countries, in Japan, Australia, Canada, and the United States the final authority in the formulation and the enforcement of quarantine regulations rests with the Federal 
Government. In a number of these countries, the state, prefectural, or provincial government may exercise authority over local outbreaks, provided it is shown that the local authorities are capable of controlling the disease to the extent of preventing the spread of infection. The central government, however, in all cases reserves the right to regulate the movement of animals whenever in the judgment of the federal authorities the infection is likely to spread to other districts.

Rinderpest is a disease that has been especially difficult to eradicate from every country into which it has been introduced. The length of time required to stamp out this infection in different countries has varied greatly and has depended upon the local methods of handling cattle and the degree to which the laws controlling the movement of animals have been performed.

In England, where the land is well fenced and cattle are, therefore, well restrained, and where respect for law is very high, infections have been stamped out within a period of two years.

In Hungary, an infection occurred in 1827 and the disease raged almost without cessation until 1842. Hungary was again infected in 1849 and the disease remained there almost unabated until 1862.

Operations against rinderpest in European Russia were marked by the passage and enforcement of a drastic act in 1879, but it was not until 1900 that the infection was entirely stamped out.

Rinderpest was unknown in Africa until 1864, when it was discovered in Egypt. It gradually spread to the south African states where the last great epizoötic occurred in 1896-97, when from 80 to 90 per cent of the cattle died.

Assisted by the Director of Agriculture, H. T. Edwards, and the chief veterinarian of the Bureau of Agriculture, Dr. S. Youngberg, I looked somewhat carefully into the rinderpest situation in the Philippines. Among others, we visited the three provinces in which the disease is most prevalent, Pampanga, Tarlac, and Pangasinan.

We inspected a number of the quarantine pens where animals affected with rinderpest were confined; observed the extent to which the regulations of the Bureau of Agriculture, with respect to the movement of animals in and out of barrios under quarantine were being obeyed; and conferred with the governors of two of the provinces, the veterinarians of the Bureau of Agriculture in charge of the local work, and the Constabulary oflicers who are charged with the enforcement of the quarantine regulations. I also took occasion to talk at length with a number of carabao 
and cattle owners, principally small farmers who own only one animal.

I am convinced from the observations made that there is little hope of completely controlling the disease, much less stamping it out, under any system of quarantine. Quarantine regulations, as has just been stated, are difficult to enforce in any country. In the Philippines, where the land is unfenced and where the animals susceptible to the disease are used principally as work stock and, therefore, cannot be confined to the owner's land without practically destroying the owner's business, and where the people have not yet been educated to appreciate the value of quarantine regulations in preventing the spread of contagious diseases, the difficulties are greatly increased.

While there seemed to be much prejudice on the part of the live-stock owners against the enforcement of quarantine regulations, there seemed to be a willingness on their part to have their animals immunized. In the Province of Pampanga, where Governor Ventura had been active in educating the people along this line, I found very much favorable interest in immunization.

If immunization is effective and feasible, and I am assured by the officials of the Bureau of Agriculture that it is both, it would seem to be the way out of the difficulty.

The Bureau of Agriculture has already immunized during the past year nearly 8,000 animals with a loss of less than 1 per cent, and at a cost for salaries of veterinarians, labor, and equipment of about 1 per animal immunized. The time required to immunize an animal varies from two to three weeks. The immunity conveyed appears to be complete and from observations extending over three or four years and from experience in immunizing against similar diseases there is every reason to believe that immunity produced by this means continues throughout the life of the animal.

Estimating the carabao to be worth $¥ 100$ and the average loss of animals due to the process of immunization to be 1 per cent, the animal owners could insure themselves against all losses by paying 1 each for the animals immunized. This money could be administered by the Government as a fund with which to compensate the owners for the loss of all animals killed. The records of the Bureau of Agriculture show a loss of less than 1 per cent and the value of cattle and carabaos of all grades and ages is perhaps less than $\$ 100$ each. Therefore, it appears that there is an ample margin of safety in allowing $\mathbb{P} 1$ per head as an insurance fund. 
According to estimates furnished me by Doctor Youngberg, rinderpest has cost the Philippine Islands in the last five years in salaries of veterinarians, inspectors, and other expenses connected with the control of this disease $¥ 2,330,823$, distributed as follows:

\begin{tabular}{|c|c|c|}
\hline $\begin{array}{l}1910 \\
1911\end{array}$ & & $\begin{array}{r}1 \times 275,661 \\
518,146\end{array}$ \\
\hline 1912 & ........................ & 591,747 \\
\hline 1913 & & 524,997 \\
\hline 1914 & 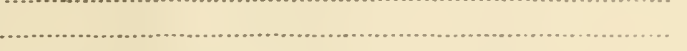 & 420,272 \\
\hline
\end{tabular}

The records of the Bureau of Agriculture, supplemented by estimates made by Doctor Youngberg, show that the animals that have died of rinderpest in the last five years were worth $¥ 2,528,900$. Thus the average annual cost to the Government to enforce rinderpest quarantine in the last five years has been $¥ 466,165$. The average annual loss to the live-stock owners on account of deaths from rinderpest in the last five years has been 505,780 . The average total annual cost of rinderpest to the people of the Philippines has been $¥ * 971,945$.

In one year, 1902, the loss from animals that died of rinderpest is estimated to have been between $* 50,000,000$ and $₹ 60,000,000$. "Many of the provinces lost from 50 to 80 per cent of their carabaos and cattle."

Doctor Youngberg estimates that 80 per cent of the infection of the Islands is in the Provinces of Pampanga, Tarlac, and Pangasinan, and that 80 per cent of the deaths, due to this disease, occur in these provinces. Doctor Youngberg further estimates that with proper facilities and support all the cattle and carabaos in these provinces, 150,000 head, can be immunized in from one to three years. The cost of this work is estimated by Doctor Youngberg to be as follows:

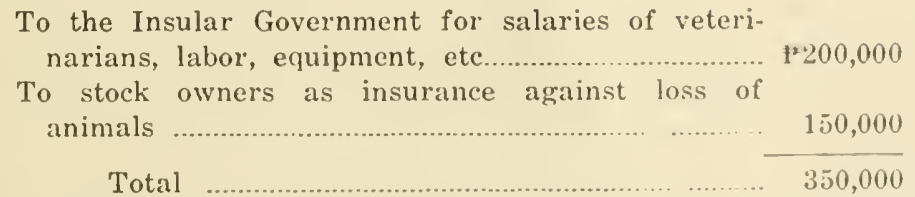

According to this estimate, which I am assured by Doctor Youngberg is conservative, the cost to the Government to immunize every animal in these provinces is slightly more than one-half as much as it has cost the Government each year in the last five years to maintain in these provinces a quarantine

${ }^{1}$ Report of the Philippine Commission, 1902, p. 293. 
which, at best, has not more than kept the disease from spreading.

The part of the expense to be borne by the owners of the calrabas and cattle is approximately one-third of the value of the animals they lose each year from the disease.

By immunizing all susceptible animals in these provinces, rinderpest will be completely stamped out in this region and all losses from the disease, excepting among the newly born and the animals introduced, would be prevented. It is estimated that an annual charge of from $\$ 50,000$ to $\$ 75,000$ would be sufticient to immunize all young stock and all animals imported into the provinces. On this basis a saving of more than $\$ 700,000$ a year would be effected, once all the animals in these provinces were immunized, and all danger of a recurrence of such an outbreak as occurred in 1902 would be removed.

With these principal centers of infection cleaned up it would be comparatively easy to remove the infection in other districts by the same process. Obviously, until all infection has been fully stamped out in the Islands, vigilance against the disease should not be relaxed by the Government or by the people.

\section{THE SUGAR WASTE}

The glaring defect in the sugar industry in the Philippine Islands is in the method of extracting the sugar from the cane. The sugar producers of the Islands cannot hope to compete successfully with those of Cuba, Java, Porto Rico, and Hawaii, while permitting 35 per cent of the sugar contained in their cane to be lost in the process of milling.

The Bureau of Agriculture has introduced and developed a number of strains of cane that promise to be more productive than those commonly grown, but the stalks are so large that they cannot be successfully milled with the present facilities. Other means of increasing the cane tonnage, such as deeper and more thorough plowing, crop rotation, the use of fertilizers, and, in some localities, irrigation are available, but these means are of secondary importance compared with correcting the defects in milling.

Apparently there is not sufficient capital among the planters to erect the required number of up-to-date sugar centrals, therefore a part of the capital for this purpose must be secured from outside sources. No one questions the necessity for better sugar mills, but there is a great lack of agreement regarding the best method of securing them.

It has been suggested by many that the Government declare 
sugar mills a public necessity and guarantee to capital invested in them an annual return of 4 per cent, as the Government has already done in the case of the railroads of the Islands.

It has been suggested by others that the Government build and operate the sugar centrals, charging the planter's enough for manufacturing their sugar to cover the cost of operation and upkeep. Also, it has been suggested that the Insular Government supply a part of the capital for the erection of sugar mills, the provincial government a part, and local planters a part.

People competent to speak on this matter assert that outside capital would be available for the erection of all the mills needed in the Islands if the Government would declare sugar centrals a public utility and would confer upon their owners the right to eminent domain with respect to the location of the mill, the right of way of its railroad tracks and switches, its pipe lines, sewers, and wharfs, and if the Government would follow the practice of some of the States in preventing destructive competition by determining what regions can support a central and allowing no public central to be erected except with a Government franchise and in a region approved by the Bureau of Agriculture. In consideration of the rights and privileges thus conferred upon the mill owners, the Government should exercise the same control over the management and operation of the sugar centrals as it exercises over other public utilities, such as railroads, telephones, and banks, with respect to the rates charged, the nature of the contract between the mill owners and the planters, the location and plans for the mill, railways, pipe lines, sewers, and wharves, and make the central subject to governmental control with respect to the efficiency of its management.

Naturally in determining what is a fair return on the investment by the mill owners, or what is a fair charge for the manufacture of the sugar from the cane, the Government would consider the management of the mill in manufacturing the sugar as well as the efficiency of the planters in the production of cane. The Government should station at each such central an efficient chemist bonded and appointed by the Government and perhaps also a weighmaster and a record clerk. The three under direct supervision of an ofticial of the Bureau of Agriculture should represent the planters and mill owners in all matters of control and record of business. The Goverment would be justified, perhaps, in taxing each central on the basis of its output. the fund to be paid into the Treasury to the credit of the Bureau of Agriculture to support the work of supervision and control.

In an era of rapid expansion of such an industry there is 
opportunity for waste and fraud in selling improperly designed machinery and in the erection of ineflicient mills. The waste in an ineflicient sugar mill is too great and too far reaching to be permitted. 'Therefore, it seems reasonable that the Government should exercise the right to pass at least upon the plans of all centrals not for the exclusive use of an individual or of a corporation.

\section{SUGAR SCHOOL}

'The Bureau of Agriculture owns 363 hectares of very good sugar land at La Carlota in the Island of Occidental Negros which at present the Bureau is using as an experiment station. The community in which the station is located is in need of a modern central. It has been suggested that the Government erect on its sugar estate at La Carlota a complete modern sugar mill, costing perhaps 160,000 , to be operated for two purposes: First, as a commercial mill for the manufacture of the sugar of the locality; and, second, as a sugar school for the education of the sugar planters of the Islands in the details of growing sugar cane and in managing sugar mills. It is thought by those who are most earnestly advocating this plan that the earnings of the mill would easily support the school.

If the sugar business is developed extensively in the Islands, there will be great demand for young men to take positions in the centrals as engineers, superintendents, and assistant chemists, and it will be altogether better to prepare young Filipinos to take these positions of responsibility than to import men from the United States, England, and Germany for this work.

An incidental but important feature of the sugar-producing business is the supply of work animals on the plantations. This in turn is dependent upon the success with which the ravages of rinderpest are controlled and upon the facilities that are provided for the introduction of work stock from Indo-China. Importation, however, should be resorted to only as a temporary relief. The birth rate in carabao, I am informed by the Director of Agriculture, exceeds the death rate by some 15 or 20 per cent a year, even under present conditions of rinderpest control. Unless, therefore, the development of the industries in the Islands should be so rapid as to absorb this natural increase in work animals, there would soon be no need of importing stock from other countries. Indeed, the Philippines should have the rinderpest under such control and should manage their carabao in such manner as soon to be exporting work animals instead of importing them. 


\section{EXPERIMENTAL AND DEMONSTRATION STATIONS}

A sharp distinction has not yet been made between experimental and demonstration work in the Philippines. While the Islands afford an unusually large variety of conditions of soil and climate, yet the agriculture of the Islands, with a few important exceptions, is comparatively uniform. One central experiment station, therefore, is sufficient for all the Philippines for the present, with special work conducted by the station in the regions where the special crops are highly cleveloped, such, for example, as tobacco work in the Cagayan Valley and sugar work in the Island of Negros.

Demonstration and test stations are means of testing the adaptability of crops and methods to the conditions of a locality, or of bringing to the attention of the people what has already been learned elsewhere. As rapidly as funds will permit, one demonstration station should be established in each province and in each subprovince. If each province or each subprovince assists in the support of the station, local interest will be quickened and a local check will be placed upon the expenditure of the funds.

In addition to these central test and demonstration stations, the Bureau of Agriculture should be provided with the funds necessary to carry on many demonstrations in coöperation with municipalities and with individuals. Crops and methods that succeed weli on the village test grounds are quickly adopted into the farm practice of the community.

\section{DISSEMINATING AGRICULTURAL KNOWLEDGE}

It has often been found as difficult to carry agricultural knowledge to the people in such form as to arrest their attention and compel them to adopt its teachings as it has been to create such knowledge. The means of reaching the farmer are limited and difficult in any country, and they are especially so in the Philippines. The pupils of the public schools, the demonstration agents, and coöperators are the most effective publicity agents available to the Government, but they alone will fall far short of fully meeting the needs of the people. The demonstration agrents come in contact with only a small part of the people and the school children are capable of carrying home to their parents only the most elementary lessons.

Placards, showing in a striking way the important results of experiments and demonstrations should be posted in the schools, post offices, municipal buildings, railway stations, and other 
public places. The coöperative societies now being formed under the auspices of the Bureau of Agriculture will be an effective means of spreading knowledge.

The newspapers of the Islands appreciate the importance of disseminating agricultural information, and are glad to coöperate fully with the Bureaus of Agriculture and Education and the College of Agriculture.

The Agricultural Revieu.-The Agricultural Review, the oflicial organ of the Bureau of Agriculture, has been a credit to the Government and has given the Philippine Islands a good name abroad. It has also served a good purpose at home in promoting progress. Strong men cannot be induced to accept positions in the Bureau of Agriculture unless they are given an opportunity to publish to the world the results of their studies, and the men now at work in the Islands cannot do their best work without some such stimulus. Only this year the United States Department of Agriculture found it necessary to establish a Journal of Agricultural Science to serve the purpose in the United States that the Agricultural Review serves in the Philippines.

One thing that has given the scientific work of the Germans and the French such commanding importance is the splendid way in which the work has been reported in their journals. We may learn a lesson of importance to the Philippines, however, from the experience of the German and French scientists. These scientists have long since abandoned the effort to meet the needs of the farmer and the needs of the scientific worker with the same publication.

Three classes of material are at present published in the Review. Articles of a simple nature intended for the benefit of the Filipino farmer. In general, these articles are of no interest outside of the Islands. The second class is material which is of value to people in the Philippine Islands and in foreign countries as well. The third class is material of a technical nature which is read by some people in the Philippine Islands, but is mainly of interest to the readers in other countries.

The Review, as published to-day in both Spanish and English, reaches not only the farmers of this generation, but also those of the next, as represented by the students in the schools of the Islands. It is sent to every municipality in the Archipelago; to every school above the primary grade; to various Government officials stationed throughout the provinces who come into contact with the people; to all the newspapers of the Philippine 
Islands, in which very many of the articles are reprinted; to all libraries and agricultural schools; and to paid subscribers.

There is more or less waste in the present plan of including the three classes of material mentioned in one publication. It would be better and also cheaper to issue two publicationsone exclusively for farmers and school children and another for students and scientists. The present Agricultural Review might be published quarterly and in English only, and contain articles of general and scientific interest. Besides having a limited circulation in the Philippines, it would be the medium of exchange with libraries and with foreign publications, which I am told already number about 250, and which the workers in the Bureau must read regularly if they are to keep abreast of the times. It will be cheaper to secure these publications through the medium of exchange than purchase.

The other publications should be published monthly in a much smaller form than the present Review and should contain only the A B C of Philippine agriculture. Nothing should be published in this journal that is not of practical use to the people of the Islands. This publication should appear in both English and Spanish and should serve as a medium for announcements of the Bureau of Agriculture, such as in seed, plant, and animal distribution; an official medium through which the members of the agricultural societies of the Philippines may be reached; a medium through which articles of permanent value may be preserved; and a publication from which reprints of official articles of special interest could be made at a very small cost for specific distribution.

This method of issuing two distinct publications would enable the editor to place the different classes of material where they would be of the greatest value. The cost would not be so great as it now is, unless it was decided to give the publication containing the practical information a much wider circulation than the Review now has. In my judgment this should be done even though the cost over the present is increased.

\section{FEEDING THE PEOPLE.}

The first duty of the agriculture of a country is to provide a suitable and ample food supply. Only a well-nourished people are capable of developing and sustaining a civilization.

No race has found rice to be a satisfactory single diet upon which to rear children or to support labor. Unfortunately, the substitution of corn in whole or in part for rice, which in many sections of the Islands could be accomplished with comparative 
ease, will not remedy the difficulty, because the deficiencies of corn are the same as the deficiencies of rice. This statement must not be construed as in any sense a disapproval of the very successful efforts of the Bureaus of Education and Agriculture to increase corn production, and to increase the use of corn as a human food. These efforts should be continued, but as a means of providing a greater quantity of basic food rather than as a means of supplying the deficiencies of rice.

Some gain will be made, as has been shown by the results of the investigations of the Bureau of Health, by encouraging people to eat unpolished instead of polished rice. But it should be remembered that the desire to eat polished rice, like the desire to eat white bread, reaches very deep into the prejudices of the human race. White bread and polished rice are everywhere the marks of respectability. Black bread and unpolished rice have at all times been considered eviclences of poverty. Of course, every reasonable effort should be made to encourage the general use of unpolished rice, but unpolished rice will furnish only a small part of the additional nutrients needed and it may be easier to supply all the protein and minerals required in other foods than to try to save the small part that is lost in the polishing process.

While it is true, as is pointed out in another part of this report, that the capacity of the Philippine Islands to produce beef, pork, and poultry is nowhere nearly utilized at present, yet these animal products will always be so dear that they will be beyond the reach of all except the well-to-do. For the masses in the Philippines as in all other tropical countries and in all densely populated countries of the Temperate Zone, fish, beans, and peas must be relied upon to supply the deficiencies of rice and white bread.

In the United States, where more meat is produced than in any other country in the world, fish is already a cheaper source of protein than is beef, pork, or poultry. That country with a rapidly declining live-stock industry is beginning to look to the development of its fisheries and to the production of peas and beans as a means of supplementing wheat and corn as food.

Germany has done much in recent years to stimulate the production and use of fish as food, by paying bounties as high as ₹4,000 toward the building and equipping of deep-sea fishing vessels and by exempting all fishing ressels, regardless of their nationality, from tonnage dues in all German ports. Specially low rates of transportation are allowed on the German railroads 
to encourage the shipment of fresh fish inland. Educational campaigns are conducted by the Government, to show the people how best to cook and serve different kinds of fish, with a view to increasing the consumption of fish, just as the Philippine Government, through its Bureau of Education, has conducted corn-cooking campaigns to encourage the more general use of corn as food. In traveling through Germany, one is constantly impressed with the degree to which the people use beans and peas as a substitute for meat, and the ruggedness and efficiency of the German people cannot be questioned.

The Japanese have been obliged to meet the same problem that presents itself to the people of the Philippines for solution. Rice is the principal crop of Japan, and polished rice is the principal diet of the Japanese, but along with rice they consume large quantities of barley, beans, and peas, as well as much fish and poultry. With the exception of barley, all the means the Japanese have employed so successfully are available in the Philippines. There is no reason why the poultry industry may not be as highly developed in the Philippines as it has been in Japan. Unfortunately, no legume has yet been found that is to the Philippines what the soy bean is to Japan, what the white navy bean and the cowpea are to the States, or what the lupines and lentils are to the Germans; but the Bureau of Agriculture and the College of Agriculture are both at work on this problem and there is every reason to expect that beans and peas will soon be found or developed that are well suited to the Islands and that are relished by the people. In the meantime, the Bureau of Education is busy teaching the people to eat a greater variety of food and to increase as rapidly as possible the use of legumes in their dietary.

\section{INCREASING THE FISH SUPPLY}

Fish is already an important part of the diet of all classes of Filipinos. It is not certain that the Philippines have as extensive fishery resources as have some other countries, but it is certain that the fishery resources of the Islands have not been developed. Since fish will not keep long in a warm climate, and since cold-storage facilities are not generally available in the Philippines, it is essential that the fishing industry be so developed that it will not be subject to interruption by any except the most violent storms and then only for the period of greatest intensity. Therefore, the fresh waters of the Islands should be kept stocked as fully as possible, fish farming should be encouraged, and deep-sea as well as shoal fishing should be 
encouraged and helped. Thus far, comparatively little effort is made to grow fish in fresh-water streams and ponds in the Philippines, although this is an important industry among the farmers of China, Japan, and Germany. In 1903, Japan had 31,000 hectares of fresh water devoted to the cultivation of carp, eel, snapping turtle, and the like, with a yearly income from this source of $11,366,500$. In ten years the annual returns have been increased more than threefold or to $\$ 4,100,000$, while the area devoted to this purpose has been enlarged only a third.

To carry on successful deep-sea fishing, it is necessary to know the exact location and extent of the fishing banks. A deep-sea fishing boat attempting to work without this information and trusting to luck to find a bank, is almost certain to fail. The determination of the location of the fishing banks is a governmental function, and, like all other work with fishes, belongs to the Bureau of Science.

There is an investigation of minor marine animal food sources and a large amount of commercial fishery work which should be carried on along with a study of the fish food supply. The preparation of isinglass is an undeveloped industry in the Philippines. The raw material for isinglass, of more value than the fish, is now thrown away. Tortoise shell is collected and marketed to a limited extent. It is the basis of a minor industry consisting of the manufacture of combs and similar articles. There is also the possibility of canning the soup made from the meat of the tortoise. The collecting and drying of sharks' fin is a minor industry requiring little capital and yielding fair returns. Trepang, or dried sea cucumbers, is a staple food of most Oriental people. In 1909 the exports of this material from the Philippines amounted to approximately $\neq 75,000$. There is the possibility of the discovery of precious coral in quantities of commercial value. Sponges of good quality are found in the Moro Province. 'The skins of crocodiles, of water snakes, and of sharks are of value for various purposes and are easily dried for sale to leather manufacturers. The pearling banks should be protected and extended. Shells of various species of mollusks are manufactured into buttons. There is a possibility of cultivating these mollusks and they should at least receive protection.

The window-shell industry seems to exist only in the Philippine Islands. The mollusk which produces this shell requires protection and artificial propagation if the export demand for the shell in the manufacture of screens, lamp shades, and artificial decorations is to be met. The possibility of the cultivation of 
this mollusk has not been worked out, although the Bureau of Science is trying to establish new beds and to extend the old beds.

Besides the actual development of the marine products, these could afford the raw material for many household industries and thus increase the earning capacity of the people, enabling them to buy better and more fish, and to improve the entire food supply.

\section{RELIEVING POPULATION PRESSURE}

Population is not evenly distributed and development is by no means uniform throughout the Philippine Islands. In some regions, as in Cebu and Siquijor, there is considerable overcrowding, while in other regions, as in the Island of Mindanao, there are vast stretches of fertile land not yet occupied. In Cebu and Siquijor apparently all the land is in cultivation that is capable of yielding a satisfactory harvest. Indeed, I saw many fields of corn or other crops that are too steep and stony to be tilled profitably, or to support the right sort of family life.

The farmers try to grow two and frequently three crops of corn on the same land each year, but the yield of all three crops is pitiably small for one crop. The land was originally fertile, but much of it is so sloping that, under constant tillage, the surface has become very badly eroded. The supply of vegetable matter in the soil is practically exhausted by long use without manure, and the soil is left without power to withstand the severe droughts that are common at some season of each year.

At first thought, the remedy would seem to be to induce a part of the people now in the overpopulated regions to move to the unoccupied lands. This, however, I am told is not easy to accomplish with the home-loving Filipino, besides, such a remedy would be only temporary at best. No country has been helped permanently, much less saved, through the emigration of its best stock. And the people who emigrate to a new country are the strongest and best people, and the weakest are left behind to become the parents of the next generation. Some plan, therefore, must be evolved under which the people may support themselves well where they are.

It is true that if the farm crops were wisely rotated, if the fields were better tilled, if improved seeds were planted, if fertilizers of the right sort were applied, and if all the other things which the Bureau of Agriculture recommends were done, the harvest would probably be sufficient to support very comfortably all the people now living in these regions. But it is idle to 
think of a farmer rotating his corn with clover or cowpeas so as to increase the subsequent yield, when the land is needed all the time to grow corn with which to support his family. It is equally futile to advise the use of fertilizers when the capital to invest in fertilizers is not available. Improvement in the system of farming will come slowly, scarcely more rapidy than the increased food, which the improvement brings, will be required by the natural increase in population and by higher standards of living.

Moreover, there is a very definite limit to the degree to which a country can be developed by means of agriculture alone. When this limit is approached, as it seems to have been in this case, further progress will come from putting the people to work in other lines of industry. Germany long ago reached the limit of her development under agriculture alone, and developed manufactories as a means of further progress. Japan's recent remarkable development has been through industrial rather than agricultural expansion. Even the United States, until recently the largest food-exporting nation in the world. is beginning to look to other countries for a part of her food and henceforth must rely upon her manufacturing industries to maintain a favorable trade balance. Thus, the Philippine Government would be following the teachings of the best experience of other people by at once setting to work to derelop manufactories.

During my visist to these Islands, I saw ships carrying away hogs, corn, and other food products which were needed as food for the people at home. Every effort should be made to change the exports of these Islands from food products, of which there are scarcely enough for home consumption, to manufactured articles, which will utilize material now going to waste and employ profitably labor that is now idle or unprofitably employed. At first, and perhaps permanently, the manufacturing industries in the Philippines must be household industries. Such industries can be quickly developed by converting the schools of the congested centers into intensely practical trade schools. When this is done there will be money available with which to support the family while legumes are grown on the land for green manure. and capital with which to buy fertilizers and other equipment necessary to farm the land to the best advantage. The combined income of an improved agriculture and a well-organized household industry would set the people well on their way toward a condition of prosperity and commercial independence. 
Setting the people at the tasks that they can best perform is the highest duty of the schools. There is in the Philippines at present a stupendous waste of human labor and of human time. I saw bands of able-bodied men and women passing through the rice fields reaping the grain with a knife, the process requiring twenty hours for each cavan of grain harvested. In other fields, I saw farmers cutting rice with a hand sickle such as was used in Biblical days. Even this ancient method so economized the time of the harvesters that only two hours were required to harvest a cavan of grain. It would seem to be an easy task to induce every farmer to make so simple a change in his method if by so doing he could cut down the cost of the harvest tenfold. But, with any people the change to more economical ways of conducting the operations of the farm is made much easier if other and more profitable tasks are at the same time provided. The necessity for economizing labor or time cannot appeal strongly to one who has little else to do.

Much of the labor of the fields in the Philippines is performed by the women. Provide tasks in the house that are more agreeable and more remunerative and the women will find their proper place in the home and will leave the farm work to the men.

\section{THE HOUSEHOLD INDUSTRIES}

The Filipino women are skillful, inclustrious, and eager to learn. Already a good beginning in household arts has been made. Last year almost $¥ 1,000,000$ worth of hats and some ₹400,000 worth of embroidery were exported from the Philippines.

The women and children of Switzerland sold $1 * 20,000,000$ worth of laces and embroidery in the United States alone last year. The States imports aproximately $\$ 70,000,000$ worth of such articles every year, nearly all of which are house made. A household industry in Japan, the silk inclustry, produces from $1,000,000$ acres of land, much of which is roadside and banks of streams, more wealth each year than is produced from all the agricultural industries of the Philippines combined.

Philippine manufactured articles are admitted into the United States duty free, while the articles manufactured in other countries with which the Filipinos would compete are taxed by the United States. Therefore, no other people are so farorably 
situated with respect to the largest market in the world for handicraft articles as are the people of the Philippines.

Hats are now one of the most important household products. Only three kinds are yet exported. Many of the remaining 20 varieties produced in the provinces are also capable of commercial development. In going about the Islands one is continually impressed with the number of American-made hats that are being worn by the Filipino people. With the material at hand and the skill that is easily acquired by the people, all the hats worn in the Islands should be produced there and the export hat trade should be greatly increased.

Embroidery is an infant industry in the Philippines. According to the statement of authoritative exporters, the supply has not met more than a fraction of the demand. The industry is now confined to a few towns near Manila and is capable of being greatly extended.

The Philippines produce a great variety of textiles on foot looms. These are now made entirely for domestic consumption. Several million pesos worth of cotton and abacá cloth are turned out each year, and in addition jusi, maguey, and other textiles are made. However, if the efforts of weavers are turned to the production of artistic articles and cloth suitable for use in the United States, the industry can be made much more remunerative than it now is. The Bureau of Education is introducing labor-saving mechanical devices which will help this industry.

Baskets are a relatively new product, having been developed for export entirely in the schools. The great number and amount of materials available for artistic export basketry, together with the efforts now being made by the schools, should result in a larger basket industry than has been developed in Japan.

If the petate mats upon which the Filipinos sleep were produced in good colors, there is no reason why they should not be salable in the United States.

There are also a great many minor industries that can become important as, for example, lace, jewelry, carving of bamboo and wood, slipper making from straws and fibers, and the making of such novelties as hand bags, brushes, and brooms from Philippine hardwoods, sea shells, and coconuts.

The work of the schools in standardizing the handicraft products and in creating new household industries is certain to produce immediate results if a satisfactory system of selling is worked out. Until a handicraft article has become well established in the markets of the world and until it is produced in 
sufficient quantities to be marketed in the regular commercial channels it is a proper function of government to find or create a market for it.

Inasmuch as the Bureau of Education is charged with establishing new industries and encouraging the introduction of developed industries into new localities, the operation of a sales department for the purchase of the articles fabricated under the supervision of the Bureau, would place under one head those departments which logically go together-that is, planning, production, and sales.

The plan proposed by the Bureau of Education and approved by the Executive Secretary, whereby the provincial governments are permitted to purchase the products of household industries from the people for cash and sell these on consignment should be put into effect.

Undoubtedly, if the business of selling household products were large enough to justify the establishment of an independent organization, it would be advantageous to keep the public schools free from a purely commercial enterprise. Until the business becomes large enough to justify the maintenance of an independent branch of the Government, however, it would seem that the best disposition of the matter would be to impose upon the Bureau of Education the duty of finding a market for these articles.

\section{THE FUTURE RESTS UPON THE SCHOOLS}

Most of the progress in all lines, and particularly in agricultural and industrial development, will be dependent upon the extent to which the school system of the Islands is developed and the direction which education takes. It is impossible to have an efficient farmer on the land and a competent wife and mother in the home unless they first be given a sound and practical education.

The sort of education the Filipino needs is not essentially different from that which is needed by other people. Everywhere the useful and the practical are being emphasized in the school course.

The Danes, the most eflicient farmers in the world, have found in the practical course of study of their public schools the touchstone of national prosperity.

Already much emphasis is laid upon agricultural and other vocational subjects in the schools of the Islands. In fact, one cannot help being impressed with the practical nature of the instruction offered in the schools and the adaptation of this 
instruction to the needs of the Filipino people. Provision is made for the training of teachers in vocational subjects in the College of Agriculture, in the Normal School, in the Vacation Assembly, and through the supervision of teaching by the officers of the Bureau of Education.

Several types of schools especially designed to train farmers have been developed. These schools grade from the provincial secondary or intermediate school, with dormitory accommodations for the students and farms of more than 1,000 acres in area to the farm settlement primary schools in which half the time of the pupil is spent in practical field work.

Instruction in vegetable gardening is a requirement of all the schools of the Islands with the exception of those which give a trade or an industrial course.

Nursery work is a feature of all intermediate school gardens, and last year almost 50,000 ornamental trees and shrubs and more than this number of fruit trees were propagated by the pupils and distributed among the farmers. Last year there were 3,100 school gardens in the Islands, and 39,900 home gardens conducted by school pupils under direct supervision. Sixty-one thousand boys and 1,800 girls received instruction in gardening.

Work in domestic science and household arts is also well developed in general. In the congested regions such as Cebu and Siquijor, instruction in household industries should receive the same emphasis that agricultural instruction has received in some of the partly developed agricultural regions of the Philippines. A provincial trade school devoted exclusively to the development of handicraft manufacture should be established in the city of Cebu. All the schools of this and other islands where population is congested should be set to work to create a household industry as a supplement to agriculture.

\section{THE SOLIDARITY OF THE PEOPLE}

It is unfortunate for any country to be divided by mountains, seas, swamps, lakes, or rivers, or other obstacles to the free intermingling, intertrading, and intermarrying of its people. A solid state or nation, uniform in soil, climate, and occupation, has common needs and all its parts progress together. A people divided into small groups or regions, with different traditions, and with unequal opportunities, develop its different parts at different rates and frequently in different directions.

Japan, with a backbone of mountains running almost the whole length of the main island, has maintained the solidarity of her 
people by a uniform language, a strong government, and, in recent years, by a well-organized system of public schools and a well laid out system of highways and railways. China, neglecting these agencies which facilitate the intermingling and intermarrying of the people, has not yet developed beyond the tribal state.

It is a government's highest duty to develop the solidarity of the people. The greatest agencies for promoting this solidarity are good transportation facilities; a well-developed commerce; a common language; good schools; the free interchange of teachers; and the free intermingling of pupils through athletic contests.

Making provision for the physical needs of the people is not all that is necessary to be accomplished. A well-nourished man or woman has a desire to enjoy the cultures of life. A civilization grows out of the surplus over and above that which is required for the mere needs of the body.

Therefore, along with the efforts to provide a better diet and to promote the solidarity of the people must go unabated the efforts to prepare the people for better ways of living. Race pride must be quickened; proper forms of recreation must be provided; and institutions of the people like the University of the Philippines, the Bureaus of Education, Health, Agriculture, and Science must be highly developed. These institutions must be made capable of carrying not only the work of the Philippines, but also a part of the work of the world. It may be said that the people of the Philippines are already weighted down with public burdens, but in the sacrifices for the common good, a people always finds its principal source of strength. 




\section{UNIVERSITY OF CALIFORNIA LIBRARY}

Los Angeles

This book is DUE on the last date stamped below.

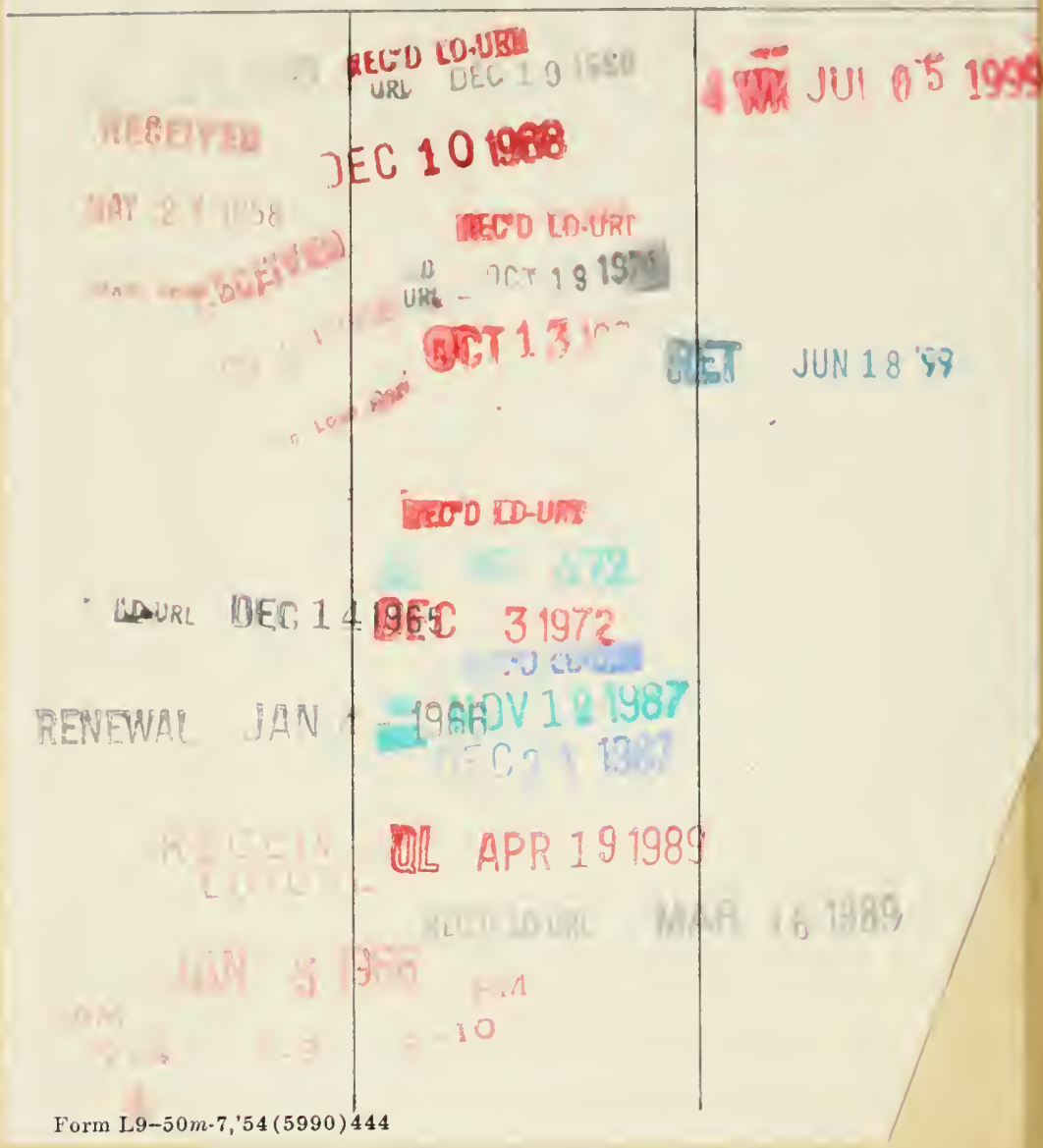


